\title{
STUDI EKSPERIMENTAL PENGUJIAN KEKASARAN PERMUKAAN DAN KEAKURASIAN DIMENSI PADA PROSES DRY MACHINING BAJA AISI 01
}

\author{
Riki Candra Putra \\ Jurusan Teknik Mesin \\ Universitas Muhammadiyah Tangerang
}

\begin{abstract}
ABSTRAK
Akhir-akhir ini proses pemesinan banyak menimbulkan dampak negatif terhadap lingkungan dan pekerja. Hal ini banyak disebabkan oleh penggunaan cairan pendingin (flood coolant) untuk mendinginkan proses pemotongan pada saat pahat memotong benda kerja.

Oleh karena itu para ilmuwan saat ini berusaha untuk mengurangi dampakdampak yang diakibatkan oleh penggunaan cairan fluida tersebut. Salah satu metode yang digunakan adalah proses Dry Machining.

Proses Dry machining adalah proses yang dilakukan pada proses pemotongan logam tanpa menggunakan fluida pendingin/cutting fluid. Proses ini dapat menguntungkan karena dapat mengurangi biaya yang besar pada proses pemesinan. Akan tetapi dry machining dapat menimbulkan temperatur yang sangat tinggi pada benda kerja dan pahat sehingga menimbulkan kekasaran permukaan yang tinggi dan ketidak akurasian dimensi.

Percobaan dilakukan dengan menggunakan salah satu jenis proses pemesinan yaitu proses pembubutan, dengan menggunakan benda kerja AISI 01 pada kekerasan yang tinggi dan pahat CBN. Penelitian ini bertujuan untuk melihat tingkat kekasaran permukaan yang terjadi dan keakurasian dimensi yang dicapat pada benda kerja.

Hasil yang didapat dari percobaan ini yaitu didapat tingkat kekasaran permukaan yang halus dan tingkat keakurasian dan penyimpangan atau variasi dimensi hingga $0.011 \mathrm{~mm}$. Manfaat yang dapat diambil dari percobaan ini adalah digunakannya $d r y$ machining sebagai dasar pertimbangan dalam menentukan metode alternatif pemotongan logam yang tepat guna.
\end{abstract}

Kata Kunci: Dry Machining, heat treatment, Keakurasian, Mesin Bubut.

\section{PENDAHULUAN}

Proses pemesinan merupakan metode pengerjaan logam yang sangat populer. Proses ini memegang peranan penting dalam industri manufaktur karena hampir semua produk yang dibuat melalui proses tuang (casting) maupun pembentukan (forming) memerlukan proses pengerjaan akhir (finishing) dengan cara di machining. Disamping itu, proses pemesinan mampu menghasilkan komponen-komponen mekanik yang mampu tukar untuk keperluan perakitan. Kelebihan lainnya adalah bahwa proses pemesinan mampu menghasilkan kekasaran permukaan yang baik sehingga proses ini sangat sesuai untuk membuat komponen-komponen mesin yang menitikberatkan pada kehalusan permukaan [1].

Salah satu benda kerja yang dilakukan proses pemesinan adalah baja AISI 01 . Material ini secara luar digunakan untuk komponen mesin, misalnya gear, piston, nozzle, dies dan cams serta untuk aplikasi perkakas pada proses pengerjaan dingin seperti roll, punch dan forging [2]. 
Akhir-akhir ini proses pemesinan banyak menimbulkan dampak negatif terhadap lingkungan dan pekerja. Hal ini banyak disebabkan oleh penggunaan cairan pendingin (flood coolant) untuk mendinginkan proses pemotongan pada saat pahat memotong benda kerja, karena untuk menghindari pemanasan yang tinggi yang dapat berakibat rusaknya benda kerja dan pahat, dampak - dampak negatif tersebut antara lain [3].

- Akibat polusi limbah cair sisa pemakaian cairan pendingin yang bisa merusak lingkungan yang disebabkan tidak tepatnya dalam penanganan sisa-sisa cairan pendingin tersebut.

- Berbahaya terhadap kesehatan operator karena reaksi kimia yang terjadi antara cairan dengan kulit.

Selain itu karena harga cairan pendingin yang begitu mahal sehingga dapat menyebabkan tingginya biaya yang harus dialokasikan oleh perusahaan hanya untuk cairan pendingin.

Oleh karena itu para ilmuwan saat ini berusaha untuk mengurangi dampak-dampak yang diakibatkan oleh penggunaan cairan fluida tersebut dengan menemukan metode terbaru adalah proses Dry $\mathrm{Ma}$ chining.

Dry machining merupakan proses pemesinan tanpa menggunakan cairan pendingin dalam memotong logam oleh pahat [3].

Akan tetapi dry machining dapat menimbulkan masalah-masalah pada proses pemesinan antara lain:

- Temperatur pahat dapat naik dengan sangat cepat, sehingga umur pahat menjadi lebih pendek.

- Keakurasian dimensi yang tidak ketat.

- Kekerasan (hardness) material dapat berkurang, material menjadi lebih ulet dan terjadinya perubahan struktur mikro dari material akibat meningkatnya temperatur.
Oleh karena itu pada penelitian ini akan dihasilkan dan dianalisa keuntungan-keuntungan dari proses dry machining dan dihindari masalah-masalah yang terjadi pada paragrap di atas.

Sehingga perlu dicari dan dikaji perumusan masalah pada penelitian ini, antara lain:

1) Bagaimana pengaruh proses dry machining terhadap kekasaran permukaan dan keakurasian dimensi.

2) Bagaimana perbandingan tingkat kekasaran permukaan teoritis dengan kekasaran permukaan sebenarnya (eksperimen).

3) Bagaimana hubungan kekasaran permukaan dengan panjang pemakanan.

4) Bagaimana kekakuan mesin bubut yang terjadi sewaktu pengerjaan benda kerja.

5) Toleransi dan keakurasian dimensi yang dicapai.

\section{TINJAUAN PUSTAKA}

\subsection{Proses pemotongan logam}

Proses pemotongan logam adalah merupakan suatu proses yang digunakan untuk mengubah suatu produk dari logam (komponen mesin) dengan cara pemotongan [4].

Proses pemotongan dengan menggunakan mesin perkakas dalam istilah teknik proses ini sering disebut proses pemesinan.

Proses pemesinan adalah proses pemotongan logam dengan pahat yang bergerak relatif terhadap benda kerja akan menghasilkan geram dan sementara itu permukaan benda kerja secara bertahap akan terbentuk menjadi komponen yang dikehendaki.

Pada proses pemesinan suatu pahat dipasangkan pada suatu jenis mesin perkakas dan dapat merupakan salah satu dari berbagai jenis pahat/perkakas potong yang disesuaikan dengan cara pemotongan dan bentuk akhir dari produk.

Gerak relatif dari pahat terhadap benda kerja dapat dipisahkan menjadi dua macam komponen gerakan yaitu gerak potong dan 
gerak makan. Pada penelitian ini proses pemesinan yang dilakukan menggunakan posisi benda kerja dalam posisi tetap dan gerak potong pahat mendekati benda kerja dan melakukan pemakanan. Kombinasi gerak potong dan gerak makan tersebut dilakukan oleh mesin bubut (Lathe).

\section{Elemen Dasar Proses Membubut}

Elemen dasar dari proses membubut dapat diketahui dengan menggunakan rumus yang dapat diturunkan. Kondisi pemotongan ditentukan sebagai berikut [4]:

$$
\begin{aligned}
& \text { Benda kerja; do = Diameter awal }(\mathrm{mm}) \\
& \mathrm{dm}=\text { Diameter akhir }(\mathrm{mm}) \\
& \text { Lt } \quad=\text { Panjang pemesinan }(\mathrm{mm}) \\
& \text { Pahat; } \quad \mathrm{Kr}=\text { Sudut potong utama }\left({ }^{\circ}\right) \\
& \text { yo }=\text { Sudut geram }\left({ }^{\circ}\right) \\
& r \quad=\quad \text { Radius ujung pahat }\left({ }^{\circ}\right)
\end{aligned}
$$

Kemudian untuk rumusan yang dipakai pada kerja mesin bubut adalah sebagai berikut:

$$
\begin{aligned}
& \mathrm{a}=\text { Kedalaman pemotongan } \frac{d o-d m}{3}(\mathrm{~mm}) \\
& \mathrm{f}=\text { Gerak makan }(\mathrm{mm} / \mathrm{r}) \\
& \mathbf{n}=\text { Putaran poros utama (benda kerja) }(\mathrm{r} / \mathrm{min})
\end{aligned}
$$

Elemen dasar dari proses membubut dapat diketahui atau dihitung dengan menggunakan rumus sebagai berikut:

1. Kecepatan potong, $V=\frac{\pi \cdot d \cdot n}{1000}\left(\frac{m}{\min }\right)$

Dimana, $d=$ diameter rata-rata

$$
=(\mathrm{do}+\mathrm{dm}) / 2(\mathrm{~mm})
$$

2. Kecepatan makan, $V_{f}=f . n(m m / m i n)$

3. Waktu pemotongan, $t_{c}=I_{t} / V_{f}$

Dalam penelitian ini hasil kekasaran permukaan dan ketelitian dimensi dipengaruhi oleh kondisi pemotongan pada mesin bubut, kondisi pemotongan tersebut digambarkan oleh beberapa variabel sebagai berikut [4]:

a. Kecepatan potong, adalah kecepatan benda kerja melintasi pahat.

b. Gerak makan (feed), adalah jarak yang ditempuh pahat sepanjang benda kerja pada suatu putaran poros utama mesin perkakas (spindle)

c. Kedalaman potong (a), adalah nilai kedalaman pemotongan yang dilakujan perkakas dan besarnya dinyatakan dalam milimeter.

\subsection{Komponen Pengerjaan Pemesinan Mesin Bubut}

Mesin bubut mencakup segala mesin perkakas yang memproduksi bentuk silindris. Akan tetapi dapat juga dipakai untuk beberapa kepentingan lain [5].

Mesin bubut yang digunakan untuk memotong benda kerja menggunakan mesin bubut konvensional dengan putaran maksimum sampai 2000 RPM, konstruksi mesin bubut tersebut pada umumnya memiliki Ekor tetap, sekerup pengarah, batang hantaran, perletakan majemuk, sadel pahat, dan apron.

\section{Sifat material pahat}

Sifat-sifat material dari pahat yang perlu dipertimbangkan adalah kekerasan, keuletan, ketahanan beban kejut termal, sifat adhesi yang rendah, dan daya larut elemtn/ komponen material pahat [4].

Bahan yang dipakai untuk pahat adalah Cubic Boron Nitride ( $C B N)$, yaitu bahan pahat yang sesuai pada pemesinan berbagai baja dalam keadaan dikeraskan (hardenned steel), besi tuang, HSS maupun karbida semen [8]

\section{Sifat material benda kerja}

Material benda kerja menjadi salah satu faktor yang sangat dominan yang dapat mempengaruhi timbulnya temperatur pada proses pemotongan. Benda kerja AISI 01 mempunyai karakteristik kemampu mesinan yang baik, stabilitas dimensi yang baik pada saat hardening, dan mempunyai kombinasi yang baik antara kekerasan permukaan dan ketangguhan sesudah hardening dan tempering [6]. 


\section{Definisi Alat Ukur}

Dalam penelitian ini untuk melihat nilai kekasaran permukaan dan kestabilan dimensi oleh karena itu perlu diketahui karakteristik dari alat ukur kekasaran permukaan dan dimensi yang dipakai, secara umum bagian-bagian utama yang membentuk sebuah alat ukur adalah [4]:

1. Sensor: bagian penghubung antara alat ukur dan benda ukur.

2. Pengubah: bagian untuk mengubah/ memperjelas isyarat dari sensor dan meneruskan kebagian penunjuk.

3. Penunjuk/pencatat: bagian penunjukkan besaran harga hasil pengukuran.

\section{Kekasaran Permukaan $\left(R_{i}\right)$}

Permukaan adalah batas yang memisahkan benda padat dengan sekelilingnya. Kekasaran permukaan adalah bentuk geometri permukaan suatu benda $[1,4]$.

Hubungan antara nilai kekasaran permukaan dengan radius mata potong pahat $(r)$ adalah: $R_{i}=\frac{f^{2}}{32 r}(\mu m)$, dimana: $\{f=$ Feed rate $(\mathrm{mm} / \mathrm{rev})\}[1]$.

\section{Dimensi dan Toleransi}

Dalam penelitian ini hasil yang diinginkan adalah tingkat ketilitian dimensi yang tinggi, maka tingkat ketelitian perlu ditambahkan bilangan toleransi pada dimensi. Toleransi adalah besar variasi yang diperkenankan pada suatu bagian tertentu atau merupakan variasi total yang diizinkan pada dimensi tertentu [5].

DImensi dengan toleransi yang ketat berarti bahwa bagian suku cadang tersebut harus pas betul dengan bagian lainnya.

\section{Perlakuan Panas pada Benda Kerja}

Dalam penelitian ini diperlukan perlakuan panas (heat treatment) yang merupakan salah satu proses yang diperlukan untuk merubah sifat-sifat material sebelum proses finishing. Perlakuan panas adalah suatu proses pemanasan dan pendinginan logam dalam keadaan padat untuk mengubah sifatsifat fisis logam tersebut [5].

Tahapan dari heat treatment yang dilakukan pada baja AISI 01 adalah sebagai berikut: Austenizing $\rightarrow$ Hardening $\rightarrow$ Quenching $\rightarrow$ Tempering $\rightarrow$ Freely by air.

\subsection{Dry Machining}

Proses dry machining adalah proses yang dilakukan pada proses pemotongan logam tanpa menggunakan fluida pendingin/ cutting fluid $[3,9]$.

Proses dry machining sangat tepat dilakukan pada baja yang sudah dikeraskan atau pembubutan material yang dikeraskan (hard turning) dengan tingkat kekerasan dari 45-70 HRC, hard turning biasa dilakukan pada proses finishing karena proses ini barada di akhir pembuatan suatu produk jadi.

Performansi yang dihasilkan dari proses hard turning apabila dilakukan pada mesin yang mempunyai konfigurasi yang baik maka akan menghasilkan penyelesaian permukaan di bawah $0.0003 \mathrm{~mm}$, nilai kesilindrisan pada $0.00025 \mathrm{~mm}$, dan pengaturan dimensi sekurang-kurangnya [12].

\section{METODOLOGI PENELITIAN}

\subsection{Diagram ALir Prosedur Penelitian}

Adapun diagram alir dari eksperimen ini adalah sebagai berikut:

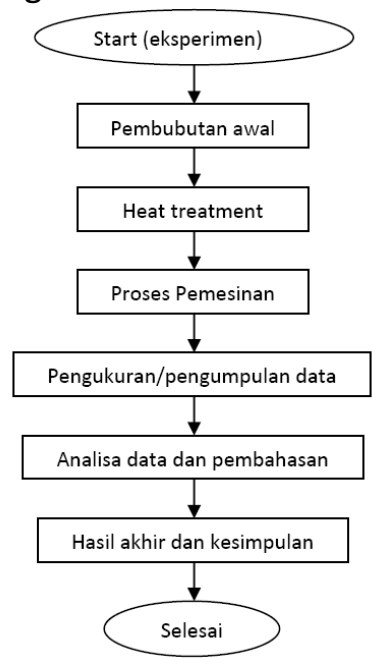


Penjelasan dari diagram alir di atas adalah:

- Pembubutan awal: pembubutan lunak, untuk menyeragamkan dimensi benda kerja.

- Heat treatment: untuk mencapai kekerasan tertentu dari benda karja.

- Dry machining: Proses eksperimen

- Pengukuran Kekasaran permukaan dan diameter benda kerja hasil eksperimen.

\subsection{Benda Kerja}

Benda uji yang digunakan adalah AISI 01. Dimana AISI 01 termasuk ke dalam golongan tool steel yaitu oil-hardening tool steels [6,13]. Benda kerja berbentuk solid bar dengan diameter $32 \mathrm{~mm}$ dan panjang 100 $\mathrm{mm}$.

\subsection{Pahat}

Pahat yang digunakan adalah Cubic Boron Nitride (CBN) yang mempunyai bentuk geometri sudut 80 derajat dan preparasi tepi merupakan gabungan antara chamfer dan honed. Radius mata pahat yang digunakan adalah $0.8 \mathrm{~mm}$.

Sifat-sifat material pahat adalah sebagai berikut:

$\begin{array}{ll}\text { Kekerasan } & : 2700 \mathrm{HV} \\ \text { Keuletan } & : 5.0 \mathrm{MPa}\end{array}$

Kekuatan Flexural : 120-130 MPa

Tool holder yang digunakan untuk uji pemotongan adalah PCLNR20K jenis righhanded dengan side cutting edge angle $5^{\circ}$. Back rake angle $-5^{\circ}$ dan side rake angle $-5^{\circ}$.

\subsection{Proses Perlakuan Panas}

Pada perlakuan panas (Heat treatment) menggunakan tungku pembakaran dengan spesifikasi sebagai berikut:

\section{Merk: Hofmann}

Buatan: Austria

Type: K1

No Pabrikasi/Thn Pembuatan: 99252/1999

Daya/Amp./Volt/Freq.: 6.6 W/9.5 A/400 V/50

$\mathrm{Hz}$

Suhu maksimum: $1200{ }^{\circ} \mathrm{C}$
Dengan tujuan untuk mendapatkan kekerasan yang tinggi maka dilakukan proses heat treatmant pada baja AISI 01 dengan tahapan proses sebagai berikut:

Austenizing (Pre-heating) $\rightarrow$ Hardening $\rightarrow$ Quenching $\rightarrow$ Tempering $\rightarrow$ Freely by air.

Untuk proses perlakuan panas pada baja AISI 01 di atas dapat digambarkan pada diagram di bawah ini.

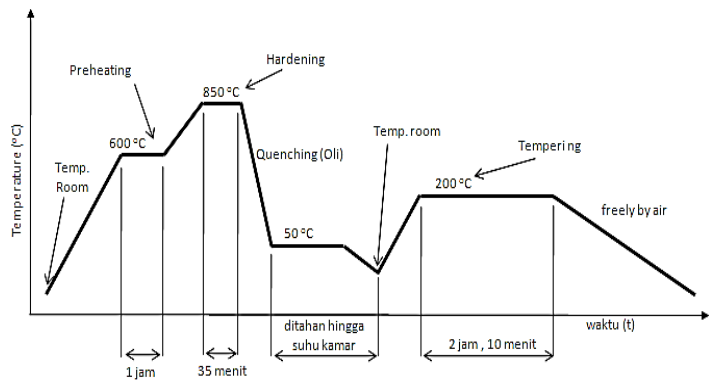

Berdasarkan proses perlakuan panas dengan tujuan pengerasan yang sudah dilakukan di atas, kemudian benda kerja dapat diuji kekerasan untuk mendapatkan nilai kekerasan.

Mesin uji kekerasan yang dipakai untuk mencari nilai kekerasan HRC adalah sebagai berikut:

Merk : WOLPERT Testor Amster/Germany

Type : Testor HT 2002

Kapasitas: Beban 150 kgf (1471 N)

Untuk mengidentifikasi benda kerja maka dilakukan stamping dengan penomoran. Dari jumlah benda kerja sebanyak 8 (delapan) buah maka didapat nilai kekerasan rata-rata sebesar $58.738 \mathrm{HRC}$.

\subsection{Variabel proses pemesinan}

Variabel yang diinginkan adalah:

- Kecepatan potong (V): $200 \mathrm{~mm} / \mathrm{min}$

- Kedalaman potong (a): $0.15 \mathrm{~mm}$

- Kecepatan Spindel (n): 2000 RPM

- Gerak Makan (f): 0.072 mm/put

\subsection{Rancangan Penelitian}

Benda kerja dengan diameter $32 \mathrm{~mm}$ akan dibubut sepanjang $50 \mathrm{~m}$ sebanyak 
delapan (8) buah.

llustrasi pemotongan adalah sebagai berikut:

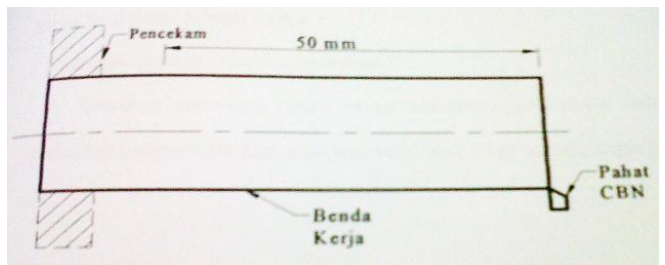

Mesin bubut yang digunakan adalah dengan spesifikasi sebagai berikut:

Type: DP $132 \mathrm{~s} / 4 \mathrm{~T}$

Merk: Voest - ALPINE (Steinel) WEILER

Buatan AUstria

Putaran motor: 2000 RPM

Sesudah di bubut benda kerja akan dilakukan proses pengukuran kekasaran permukaan dan pengukuran diameter.

\subsection{Pengukuran Kekasaran Permukaan}

Alat pengukur kekasaran permukaan menggunakan Rauchness Tester merk Mitutoyo SJ-201 dengan trace of length 5.6 $\mathrm{mm}$, cut of length $0.8 \mathrm{~mm}$.

Kekasaran permukaan dengan satuan mikrometer $(\mu \mathrm{m})$ diukur sebanyak 3 titik setiap $5 \mathrm{~mm}$ mulai dari pertama kali ujung pembubutan, yaitu mulai dari jarak $5 \mathrm{~mm}$ sampai dengan jarak $15 \mathrm{~mm}$, sehingga jumlah titik pengukuran sebanyak $3 \times 24=72$ titik.

Tabel Hasil pengukuran kekasaran permukaan adalah sebagai berikut:

\begin{tabular}{|c|c|c|}
\hline $\begin{array}{c}\text { rata-rata } \mathrm{Ra}_{1} \\
\text { (jarak } 5 \mathrm{~mm} \text { ) }\end{array}$ & $\begin{array}{c}\text { rata-rata } \mathrm{Ra}_{2} \\
\text { (jarak } 5-10 \mathrm{~mm} \text { ) }\end{array}$ & $\begin{array}{c}\text { rata-rata } \mathrm{Ra}_{3} \\
\text { (jarak } 10-15 \mathrm{~mm} \text { ) }\end{array}$ \\
\hline $0.605 \mu \mathrm{m}$ & $0.573 \mu \mathrm{m}$ & $0.548 \mu \mathrm{m}$ \\
\hline
\end{tabular}

Didapat nilai rata-rata kekasaran permukaan sebesar $0.575 \mu \mathrm{m}$.

\subsection{Pengukuran Diameter rata-rata}

Diameter benda kerja diukur dengan menggunakan sigmat tiap jarak $2 \mathrm{~mm}$ mulai dari ujung pembubutan sampai jarak $46 \mathrm{~mm}$. Lihat ilustrasi pengukuran berikut:

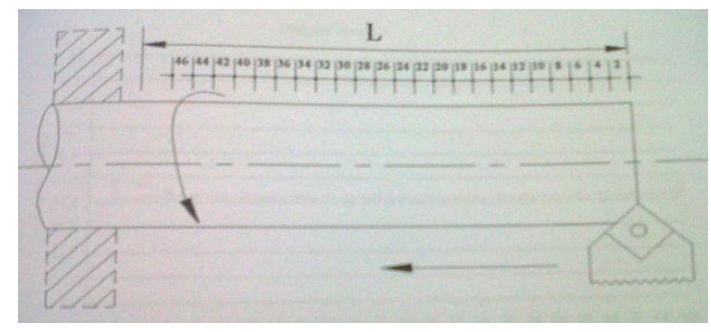

Pengukuran dilakukan sebanyak 115 titik pada satu sampel dan pada jumlah 8 sampel didapat jumlah data pengukuran sebanyak 920 data diameter, dengan nilai diameter pengukuran $\left(d_{p}\right)$ adalah $31.68 \mathrm{~mm}$

Kemudian dihasilkan selisih antara diameter pengukuran $\left(d_{p}\right)$ dari benda dengan diameter awal $\left(d_{0}\right)$ dari benda dengan rumusan: $\Delta d=d_{0}-d_{p}$, dan nilai selisih tersebut menjadi nilai penyimpangan dimensi rata-rata benda dengan nilai maksimum adalah $0.029 \mathrm{~mm}$ dan nilai minimum 0.013 $\mathrm{mm}$.

\section{PENGOLAHAN DATA DAN PEMBA- HASAN}

Kemudian dihitung nilai teoritis dari kekasaran permukaan, keakurasian dimensi dan hubungan antara kekakuan mesin dan kekasaran permukaan sebagai berikut:

\subsection{Perhitungan Kekasaran Permukaan}

Dengan memasukkan nilai variabelvariabel pemotongan didapat elemen-elemen dasar dari proses membubut antara lain:

Menghitung diameter rata-rata:

$$
\begin{gathered}
d_{\text {rata-rata }}=\frac{d o-d m}{2}=\frac{(32-31.68) \mathrm{mm}}{2} \\
=31.84
\end{gathered}
$$

Kecepatan potong (V):

$$
\begin{aligned}
V= & \frac{\pi \cdot d \cdot n}{1000}=\frac{\pi \times 31.84 \mathrm{~mm} \times 2000 \mathrm{rpm}}{1000} \\
& =199.9 \mathrm{~m} / \mathrm{min} \approx 200 \mathrm{~m} / \mathrm{min}
\end{aligned}
$$




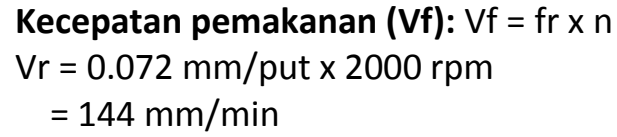

Waktu pemotongan: $\mathrm{tc}=\mathrm{It} / \mathrm{Vf}$

$$
\begin{aligned}
& =(50 \mathrm{~mm}) /(144 \mathrm{~mm} / \mathrm{min}) \\
& =0.347 \mathrm{menit}
\end{aligned}
$$

$\mathrm{fr}=$ Gerak pemakanan ( $\mathrm{mm} /$ put)

$\mathrm{It}=$ Panjang benda kerja $(\mathrm{mm})$

$\mathrm{n}=$ putaran spindel (rpm)

$r=$ radius mata potong $(\mathrm{mm})$

Nilai kekasaran permukaan ideal (Ri):

$$
R i=\frac{f r^{2}}{32 r}=\frac{0.072 \mathrm{~mm} / \mathrm{put}^{2}}{32 \times 0.8 \mathrm{~mm}}=0.2025 \mu \mathrm{m}
$$

Nilai di atas adalah nilai teoritis yang didapat dengan memasukkan variabel pemotongan.

\subsection{Standar Deviasi}

Standar deviasi digunakan untuk mengukur tingkat keakurasian proses dan tingkat penyimpangan atau variasi yang terjadi pada pengukuran diameter produk

$$
S=\sqrt{\frac{\sum\left(X_{i}-\bar{X}\right)^{2}}{n-1}}
$$

contoh pada sampel nomor 1 dengan nilai selisih nilai diameter benda $(\mathrm{Xi}-\mathrm{X})^{2}=2.6 \times 10^{-3}$ $\mathrm{mm}$ dan jumlah pengukuran sebanyak 5 pada satu sampel maka:

$S=\sqrt{\frac{2.6 \times 10^{-3}}{5-1}}=0.025$ maka nilai rata-rata $S$ pada keseluruhan sampel (8 sampel) adalah: 0.011 .

\subsection{Kekakuan Mesin (Cr)}

Nilai rata-rata kekasaran permukaan (Ra) adalah $0.576 \mu \mathrm{m}$, maka

$$
C_{r}=\frac{R_{a} \cdot 8 \cdot r}{f_{r}{ }^{2}}=\frac{0.576 \times 8 \times 0.8}{0.072^{2}}=711
$$

Nilai konstanta $\mathrm{Cr}$ adalah 711 merupakan sistem yang kaku karena untuk kekakuan mesin mempunyai kekakuan terbaik dibawah harga Cr 2000.

\subsection{Hubungan $\mathrm{Cr}$ dengan $\mathrm{Ra}$}

Semakin kecil nilai kekasaran permukaan (Ra) maka semakin besar nilai kekakuan mesin, dan nilai gerak pemakanan (fr) merupakan nilai yang diharuskan jika ingin mendapatkan kekasaran permukaan yang rendah.

\subsection{Hubungan Ra dengan $\Delta d$}

Nilai kekasaran permukaan (Ra) menurun dengan bertambahnya panjang pemakanan sepanjang benda kerja dengan penjang pemotongan $46 \mathrm{~mm}$.

Hal ini disebabkan oleh adanya defleksi

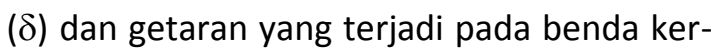
ja yang diakibatkan gaya potong dari pahat, semakin panjang benda maka defleksi dan getaran pada ujung benda kerja akan semakin besar, sehingga getaran yang timbul akan besar pada awal panjang pemakanan.

\subsection{Perbandingan $\boldsymbol{R i}$ dan $\boldsymbol{R a}$}

Perbandingan kekasaran permukaan teoritis (Ri) dan kekasaran permukaan eksperimen ( $\mathrm{Ra}$ ) terdapat adanya perbedaan, hal ini disebabkan oleh adanya pengaruh temperatur pemotongan yang tinggi, dan getaran eksitasi mandiri (chatter).

Harga parameter kekasaran permukaan eksperimen ( $\mathrm{Ra}$ ) diatas merupakan suatu bentuk kekasaran yang halus, dapat dibandingkan pada tabel berikut [17]:

\begin{tabular}{|l|l|l|}
\hline $\begin{array}{c}\text { ISO } \\
\text { Number }\end{array}$ & $\begin{array}{c}\text { Mean } \\
\text { Raughness } \\
(\text { Ra } ; \mu \mathrm{m})\end{array}$ & \multicolumn{1}{|c|}{ Keterangan } \\
\hline N12 & 50.0 & - Sangat Kasar \\
\hline N11 & 25.0 & \\
\hline N10 & 12.5 & - Kasar \\
\hline N9 & 6.3 & \\
\hline N8 & 3.2 & - Normal \\
\hline N7 & 1.6 & \\
\hline N6 & 0.8 & \\
\hline N5 & 0.4 & - Halus \\
\hline N4 & 0.2 & \\
\hline N3 & 0.1 & - Sangat halus \\
\hline
\end{tabular}




\subsection{Keakurasian Dimensi Benda kerja}

Toleransi dan keakurasian dimensi diameter benda kerja dengan menggunakan mesin bubut konvensional adalah sebagai berikut:

- $\quad$ Nilai selisih diameter terjadi lebih besar pada posisi pengukuran jarak $2.4 \mathrm{~mm}$ dan $6 \mathrm{~mm}$ karena pengaruh getaran dan defleksi yang besar.

- $\quad$ Nilai selisih diameter rata-rata $(\Delta \mathrm{d})$ yang maksimum adalah $0.029 \mathrm{~mm}$ dan minimum adalah $-0.013 \mathrm{~mm}$, besar kecilnya nilai $\Delta$ d diukur dari jarak nilai standar 0 .

- $\quad$ Nilai positif $(+)$ berarti nilai selisih $\Delta d$ benda kerja lebih besar dan nilai negatif (-) berarti nilai $\Delta$ d lebih kecil, yang dipengaruhi kedalaman potong (a), getaran dan defleksi benda kerja.

\section{KESIMPULAN DAN SARAN}

- Dry machining dapat dilakukan pada proses pemesinan yang memerlukan tingkat kekasaran permukaan yang rendah dan tingkat keakurasian dimensi yang tinggi.

- Nilai kekeasaran permukaan eksperimen adalah $0.576 \mu \mathrm{m}$ dan keakurasian dimensi berdasarkan nilai standar deviasi (S) adalah 0.011.

- Nilai kekasaran permukaan eksperimen yang didapat adalah tingkat permukaan dengan keterangan halus atau sama dengan ISO number N5.

- Agar data lebih teliti sebelum eksperimen sebaiknya mesin dicek kepresisiannya.

- Perlu dilakukan penelitian untuk mencari hubungan antara kekasaran permukaan, keakurasian dimensi dan kekakuan mesin, serta ditentukan hubungan antara variabelvariabel pemotongan dan pengaruhnya terhadap kekasaran permukaan.

\section{DAFTAR PUSTAKA}

[1] ST., MT, Wiyono Slamet. 2005. Proposal penelitian "Pengembangan model empiris untuk memprediksi kekasaran permukaan pada finish hard turning". Universitas Sultan Ageng Tirtayasa, Jurusan Teknik Mesin.

[2] Wiyono Slamet, AS Danardono, Kiswanto Gandjar. 2005. Pengaruh parameter pemesinan terhadap kualitas permukaan baja DF-3 (AISI O1) yang dikeraskan. JURNAL TEKNOLOGI Universitas Indonesia, Edisi No.3, tahun XIX, September, 179-265.

[3] Shefelbine Wendy and Dornfeld A. 2004. David. The Effect of Dry machining on burr size, the Journal of Consortium and Edge Finishing. University of California, Berkeley.

[4] Hartanto Agus. Tugas Akhir. 2003. Analisa pengujian umur pahat dan kekasaran permukaan pada benda kerja ST 42. Universitas Mercubuana, Jurusan Teknik Mesin.s

[5] Amstead, B.H. 1990. Teknologi Mekanik, Jakarta. Erlangga.

[6] Corus Engineering Steels. Cold work tool steel to AISI 01.

http://www.corusnz.com/downloads/To olsteel_AISIO1.pdf\#search='AISI\%2001'

[7] Ozel Tuqrul and Karpat Yigit. 2004. Predictive modeling of surface roughness and tool wear in hard turning using regression and nural networks. Int., Journal of machine toolds and manufacture 45 (2005) 467-479. University of New Jersey.

[8] http://www.mothersontools.com/cbn_h 
ard_steel_adv.thm

[9] Feng, C, Shaw. Hattor, Mitsuro. Cost and Process Information Modelling for Dry Machining. Manufacturing Engineering Laboratory NIST, DoC and AIST, MITI.

[10] Graham Don, Huddle Dave and McNamara Dennis. 2005. Feature Article - Machining Dry is Worth A Try. Fro MMS Online ${ }^{\mathrm{TM}}$.

[11] Ozel Tuqrul, Hsu Kong-Tsu, and Zeren Erol. 2005. Effect of cutting edge geometry, workpiece hardness, feed rate and cutting speed on roughness and forces in finish turning of hardened AISI H13 steel. Intl J Adv Manuf Technol page 25:262-269. University of New Jersey.

[12] Soroka, P, Daniel. 2003. Hard Turning and the machine tool, Hardinge Inc.

[13] Metal Handbook. Heat treating cleaning and finishing. Eighth edition. Volume 2. American Society for Metal (ASM).

[14] Web master www.kyocera.com

[15] http://global.kyocera.com/prdct/tool/ce ratip/repert/CBN.html

[16] Ariani Wahyu Dorothea. 2004. Pengendalian kualistas statistik (Pendekatan kuantitatif manajemen kualitas). Penerbit ANDI Yogyakarta.

[17] Rochim, T. 1993. Teori dan Teknologi Proses Pemesinan, Laboratorium Teknik Pro-duksi dan Metrologi Industri, Jurusan Teknik Mesin, FTI, ITB, Bandung. 